\title{
Саркисова И.В. \\ К вопросу о сущности понятия «наставничество» в зарубежной и отечественной литературе
}

ФГБОУ ВО «Тольяттинский государственный университет» (Россия, Тольятти)

doi: $10.18411 / l j-02-2021-161$

idsp: ljournal-02-2021-161

\section{Аннотация}

В данной статье рассмотрены вопросы исторического развития института наставничества в России и за рубежом. Целью статьи является проведение анализа «понятия» наставничества в Российской и зарубежной литературе. Рассмотрено наставничество как актуальная проблема в теории и практике сопровождения молодых педагогов. Выявлены различия и особенности в понятиях «наставничество», «тьюторство», «коучинг», «менторство». Сделаны выводы о необходимости развития системы наставничества молодых педагогов в современных условиях.

Ключевые слова: наставничество, тьюторство, коучинг, менторство, профессиональные компетенции

\section{Abstract}

This article examines the historical development of the institution of mentoring in Russia and abroad. The aim of the article is to analyze the conceptual form of mentoring in Russian and foreign literature. Mentoring as a topical problem in the theory and practice of young teachers support is considered. Differences and features in the concepts of "mentoring", "tutoring", "coaching", "mentoring" are revealed. Conclusions about the need to develop a mentoring system for young teachers in modern conditions are made.

Key words: mentoring, tutoring, coaching, mentoring, professional competencies

В настоящее время наставничество приобретает все большее значение в управлении процессом развития персонала, повышения качества, скорости вхождения в профессию и инновационной активности. Для образовательных организаций наставничество так же представляет огромный интерес. На возрождение института эффективного наставничества нацелены национальные проекты и современные научные исследования.

Анализ последних исследований и публикаций дает основания утверждать, что к проблеме наставничества, как в теоретическом, так и в практическом плане было обращено внимание ученых во все времена. Теория наставничества берет свое начало из эпохи античности (Сократ, Платон, Аристотель, Сенека) и Средних веков (Винсент из Бове, П. Абеляр, Ф. Аквинский, Эразм Роттердамский, Н. Макиавелли). В 16-20 веках к проблеме наставничества обращались митрополит Илларион, В. Мономах, Ж. Ж. Руссо, И. Песталоцци, Я. Коменский, К. Ставровецкий, К. Д. Ушинский, В. А. Сухомлинский, В. С. Макаренко, В.А. Сластенин и др. Сущность понятия наставничества раскрыли в своих трудах С.Г. Вершловский, С.Я. Батышев, Л.Н. Лесохина, В.Г. Сухобская и др.

В настоящее время вопросам наставничества уделяется большое внимание как в зарубежной теории образования, так и в России. Е.Н. Фомин, трактуя понятие наставничества, определяет его как «личностно ориентированный педагогический процесс», призванный помочь начинающему работнику овладеть профессией, определить для себя её значимость в своей жизни. Наставничество способно создать условия, при которых приобретается широкий ряд профессиональных компетенций и индивидуальный опыт решения ощутимых задач производства. Автором выделяется одна из перспективных форм наставничества, заключающаяся в том, что молодой 
человек ориентирован на пример своего наставника. Указанная форма способствует стимуляции молодого работника приобретать навыки, которые присущи его наставнику, способствует адаптации на производстве, в организации [8]. Ю.Л. Львова при раскрытии понятия «педагогическое наставничество» указывает, что оно является процессом «творческого сотрудничества», «парного содружества», которое возникает на основе единых педагогических взглядов, методических поисков и желания совместно решать творческие задачи, в основе которых лежит общение [2].

Зарубежные авторы (Г. Льюис, Д. Меггинсон, Л. Рай и др.) понятие «наставничество» изучают в контексте деятельности менеджеров по управлению персоналом. Одним из первых определил наставничество в качестве существенной помощи персоналу, который нуждается в перспективном видении своих возможностей английский исследователь Дэвид Меггинсон [4]. В издании «Развитие навыков эффективного общения» Л. Рай указывает на наставничество как на «самый важный и успешный метод развития человека», рассматривая наставничество в качестве «процесса передачи навыков от руководства подчинённым» [4].

Дэвид Клаттербак особо выделяет умение наставника совместить в себе роли родителя и сверстника с целью сопровождения молодой личности на переходном этапе её развития и определяет наставника как «человека, обладающего опытом, готового делиться своими знаниями с менее опытными людьми в обстановке взаимного доверия». Наставничество, по его мнению, совмещает в себе фисилитацию, коучинг, консультирование и создание сети контактов, чтобы воодушевить и поощрить учеников за отношение к своей деятельности [4]. Г. Льюис рассматривает наставничество как «систему отношений и «ряд процессов», где один человек предлагает помощь, руководство, совет и поддержку молодому специалисту на рабочем месте. Также наставник обеспечивает подопечному эффективный способ адаптации к профессии» [3].

Наряду с термином «наставничество» используют такие понятия, как «тьюторство», «коучинг», «менторство». Однако понятия «ментор», «тьютор», «коуч», «фасилитатор» имеют свои особенности.

«Коуч» (англ. Couch - тренер) - это опытный сотрудник, который умеет организовать процесс обучения, основываясь на партнёрских взаимоотношениях, может вдохновлять обучающихся на поиск решения проблем самостоятельно [7]. Коучинг способствует обеспечению раскрытия потенциала личности обучаемых.

«Ментор» (от лат. Mentos - намерение, цель, дух; mon-i-tor - тот, кто наставляет) - руководитель, наставник, учитель, воспитатель, надзиратель [7]. Имя Ментора носил герой древнегреческой мифологии, мудрый советчик, который пользовался всеобщим доверием. Менторинг - это целенаправленная передача опыта более опытным сотрудником стажёру по типу «делай как я». Слово «ментор» нередко можно услышать от политиков, спортсменов, актёров и многих других, когда они описывают человека, выбранного ими в качестве ролевой модели, или того, кто оказал значительное влияние на судьбу, карьеру, то есть на ход развития самого человека.

Очень часто наставничество отождествляют с менторством и тьюторством. В менторстве мы видим сочетание элементов коучинга и деятельности преподавателя. В деятельности ментора первоначально происходит изложение теоретических основ рассматриваемого процесса, далее следует пояснение изложенного на практике, впоследствии ментор предлагает обучаемым задания и следит за их выполнением.

«Фасилитатором» (англ. facilitator, от лат. Facilis - лёгкий, удобный) является опытный руководитель, который обеспечивает успешную коммуникацию группы с использованием креативных моделей копроративного обучения [7].

«Тьютор» - «tuior» в переводе с английского - педагог-наставник, преподаватель- консультант. Этимология этого слова (лат. tueor - заботиться, оберегать) связана с понятиями «защитник», «покровитель», «страж» [3]. Впервые в 
истории позиция тьютора была введена в Оксфордском, а чуть позднее в Кембриджском университетах Великобритании еще в XII веке. Позиция тьютора была введена как позиция старшего, сопровождающего процесс формирования каждым студентом собственной образовательной программы и оказывающего консультации в ответ на их конкретные образовательные запросы [3]. Тьютор - консультант, куратор, преподаватель, помогающий обучающимся в их саморазвитии, освоении программы образования, повышении квалификации или переподготовке. Сопровождать, помогать, быть рядом с подопечным на всем его образовательном пути - основная задача тьютора. Тьюторство особо развито в системе образования, особенно в его дистанционной форме. «Тьюторинг» нацелен на сопровождение процесса корпоративного обучения стажёра, на обсуждение вопросов о переносе опыта полученных знаний в профессиональную деятельность. Разница состоит в том, что задача тьютора - оказание поддержки к новым условиям обучения в адаптационный период, а наставник оказывает помощь и поддержку в период адаптации к профессии и условиям жизни в коллективе.

В русском языке с середины 17 века слово «наставник» означало «учитель, воспитатель». Но со временем оно было вытеснено из разговорной речи и в словаре С.И. Ожегова появилось как книжное, устаревшее значение слова «учитель», «руководитель» [6]. При обращении к толковым и этимологическим словарям мы видим различные толкования термина. Наставник трактуется как учитель, руководитель, преподаватель, воспитатель, инструктор, а также вождь, гуру, мэтр, назидатель, нравоучитель, пастырь и др. Определения различаются по сути. В слове «наставник» присутствует приставка «на-» и корень «-став-» (от глагола «ставить»), то есть наставить (например) на путь, по которому ученик дальше будет идти самостоятельно.

Современная педагогическая наука под наставничеством понимает поддержку учащегося, студента, начинающего рабочего, при помощи которой происходит более эффективное распределение личностных ресурсов, самоопределение в профессиональном и культурном отношении, формирование гражданской позиции.

Таким образом, наставник - это личность, которая осуществляет подготовку и целенаправленное воспитание работников. Наставник наряду с обучением новой профессии вводит нового работника в сферу социально-психологических отношений, через которые происходит реализация профессиональной роли молодого специалиста.

В современном контексте изучения проблемы наставничества открытым остается вопрос о его эффективности. Так, проведенное мониторинговое исследование эффективности системы наставничества в условиях модернизации педагогического образования (данные Москвы) показало, что 78\% участников (молодые учителя, наставники, методисты, руководители образовательных учреждений) считают наставничество эффективной формой работы с молодыми специалистами; 70\% молодых учителей считают, что деятельность наставника повлияла на их успешное профессиональное становление. Однако отношение к наставничеству со стороны опытных специалистов скорее негативное. $60 \%$ работников не планируют помогать молодым специалистам, лишь $15 \%$ опрошенных работников согласны делиться с молодежью опытом [1]. Итак, восстановление института наставничества является в современной теории и практике непрерывного образования чрезвычайно острой и актуальной проблемой, требующей специального исследования.

Выводы. Система наставничества является одним из ярких воплощений в повседневной жизни, а в производственной практике - традицией глубокого усвоения всего лучшего, передового, выработанного нашим обществом в процессе становления, развития и передачи этого бесценного приобретения молодому поколению. Воспитанию молодой смены рабочего класса, формированию из молодых рабочих не только мастеров своего дела, но и безгранично преданных строителей нового общества 
отдают наставники свои добытые нелегким трудом знания, умения, навыки, а вместе с тем рабочую закалку, любовь к родной стране.

В современных условиях в связи с изменением политической и социальноэкономической ситуации отношение к наставничеству изменилось, но не утратило своей актуальности. Однако наставничество претерпело трансформацию по виду деятельности: на современном этапе происходит переосмысление категории «наставничество». Наставничество распространяется не только на профессиональную сферу и сферу общественных взаимоотношений, но и на образование, воспитание, профессиональную подготовку в вузе [5].

Правильная организация системы наставничества способна не только передать профессиональный опыт последующим поколениям, но также оказывать влияние на процесс воспитания молодых сотрудников, на атмосферу организации.

Наставничество является эффективным средством, способствующим профессиональному развитию, при помощи которого сотрудники организации могут достигнуть намеченных профессиональных успехов, карьерных целей. Высока результативность наставничества при повышении эффективности использования кадровых ресурсов.

\section{$* * *$}

1. Бевз Е. В. Наставничество как условие профессиональной подготовки бакалавров педагогического образования / Е. В. Бевз / / среднее профессиональное образование: ежемесяч. теорет. и науч.метод. журн. - 2011.

2. Львова Ю.Л. Творческая лаборатория учителя: Книга для учителя. М.: Просвещение, 1992. С. 30

3. Льюис, Г. Менеджер-наставник. Стратегия раскрытия таланта и рас- пространения знаний / Г. Льюис. - М., 1998.

4. Рай Л. Развитие навыков эффективного общения. СПб.: Питер, 2002. С. 231.

5. Руденко И.В., Ошкина А.А. Проектирование апостериорной модели профессиональной подготовки будущих педагогов в вузе//Азимут научных исследований: педагогика и психология. 2020. Т. 9 № 2(31). С. 225-229.

6. Технология наставничества: опыт использования вариативных моделей наставничества: сборник методических рекомендаций для руководителей и педагогических работников образовательных организаций / Авт.-сост.: Н.А. Криволапова, В.Д. Ячменев, О.Т. Кулешова; ГАОУ ДПО ИРОСТ. Курган, 2019. - 56 с.

7. Тюмасева 3.И., Орехова И.Л., Яковлева Н.О. Адаптационный этап процесса профессиональной социализации студентов педагогического вуза // Образование и наука. 2018. Т. 20, №1. С. 75-95.

8. Фомин Е. Н. Диверсификация института наставничества как потенциал успешной адаптации молодого специалиста / Е. Н. Фомин // Среднее профессиональное образование: ежемесяч. теорет. и науч.-метод. журн. - 2012. - № 7. - С. 6-8.

\section{Сижажева O.A. \\ Музыкальное образование в Кабардино-Балкарии: традиции и современность} Северо-Кавказский государственный институт искусств (Россия, Нальчик)

doi: $10.18411 / l j-02-2021-162$

idsp: ljournal-02-2021-162

\section{Аннотация}

В статье исследуется проблема развития системы профессионального музыкального образования в одном из субъектов Российской Федерации - КабардиноБалкарской Республике. Актуальность исследования заключается в том, что на сегодняшний день существует необходимость восполнения пробела в изучении системы музыкального образования в указанном регионе. Новизна состоит в том, что заявленная тема впервые изучается сквозь призму исследования проблемы соотношения традиционного и инновационного в рассматриваемой системе. Главное внимание акцентируется на современном состоянии системы музыкального 